\title{
Microstructure, Mechanical Properties and Wear Behaviour of Semi- solid Stir Casting SiC Reinforced Zn-40Al Based Composites
}

\author{
G. H. Geng ${ }^{1}$, D.X. Wang ${ }^{2}$, P. H. Xue ${ }^{1}$, and F. Y. Dong ${ }^{1, *}$ \\ ${ }^{1}$ School of Materials Science and Engineering, North Minzu University, Yinchuan, China \\ ${ }^{2}$ Northwest Rare Metal Materials Institute, Yejin road,Shizuishan, China
}

\section{Abstract}

The $\mathrm{Zn}-40 \mathrm{Al}$ composites with various contents of $\mathrm{SiC}$ were fabricated by the semi-solid stir casting process. The influence of the $\mathrm{SiC}$ on the microstructure, mechanical properties and wear behavior of the composites were investigated. Microstructure analysis shows that the microstructures of as-cast $\mathrm{Zn}-\mathrm{Al}$ alloys are refined by the addition of $\mathrm{SiC}$. However, with the increase of $\mathrm{SiC}$ content, a number of shrinkage porosity occur. The hardness of the composites increases with the increase content of SiC. The tensile strength of the composites declines significantly with the increase content of SiC. The most effective strengthening achieves in $\mathrm{Zn}-40 \mathrm{Al} / 0.5 \mathrm{wt} . \% \mathrm{SiC}$, with a maximum increment of $20 \%$ in tensile strength compared to non-SiC addition alloy. The overall results reveal that the composites possess similar friction coefficients but the abrasion loss is reduced to less than a tenth after adding $0.5 \% \mathrm{SiC}$.

\section{Publication History:}

Received: October 17, 2018

Accepted: December 13, 2018

Published: December 15, 2018

\section{Keywords:}

Zinc matrix composite; Semisolid stir casting; $\mathrm{SiC}$ particles; Mechanical properties; Friction coefficient

\section{Introduction}

Metal matrix composites (MMCs) have many advantages compared with monolithic metals like higher specific modulus, higher specific strength, better properties at elevated temperatures and lower coefficient of thermal expansion [1]. MMCs have recently been used as critical structural applications duo to the combination of superior mechanical properties such as better tensile strength, elastic modulus, wear resistance and high temperature stability in comparison with the parent matrix alloys [2]. Zinc-aluminum ( $\mathrm{Zn}-\mathrm{Al})$ alloys containing a spot of copper have prove to be possible as cost and energy effective substitutes for a variety of bronze, cast iron and aluminum alloys in bearings and as a structure material because of their higher strength, better wear resistance, lower casting temperature and abundant resources [3,4]. These alloys are used as an alternative material for bronze and aluminum alloys because of their good tribological properties. They have shown satisfactory service performance when used for the components such as bearings, punches and seals in which high mechanical properties and wear resistance are required [5].

In order to take advantage of and improve its basic properties, reinforcing $\mathrm{Zn}-\mathrm{Al}$ alloys with ceramic materials has been explored [6] The use of reinforcements such as silicon carbide $(\mathrm{SiC})$ and alumina $\left(\mathrm{Al}_{2} \mathrm{O}_{3}\right)$ has ameliorated in hardness, strength, specific strength, wear and creep resistance of $\mathrm{Zn}$ - $\mathrm{Al}$ based composites [7,8]. Among the plenty of manufacturing processes available for discontinuous MMCs, semi-solid stirring is generally accepted as a particularly promising route $[9,10]$. Its advantages lie in its simplicity, flexibility and applicability to a large quantity production and also it is the most economical of all available routes for MMCs [11]. Before semi-solid stirring process, $\mathrm{SiC}_{\mathrm{p}}$ were pretreated. $\mathrm{SiC}_{\mathrm{p}}$ was pretreated to form a layer of $\mathrm{Cu}$ film on it, which prevented the interfacial reaction with molten $\mathrm{Zn}-\mathrm{Al}$ alloys and improved the wettability between the reinforcements and the matrix alloy.

In the present study, the $\mathrm{Zn}$-40Al composites with different contents of $\mathrm{SiC}_{\mathrm{p}}$ were successfully fabricated by semi-solid stirring technique. Subsequently, the effects of $\mathrm{SiC}_{\mathrm{p}}$ contents on the microstructure, mechanical properties and wear behavior of the composites were investigated.

\section{Experimental Procedure}

\section{Material}

Commercial pure zinc (Zn-99.99wt. \%) and aluminum (Al$99.97 \mathrm{wt}$. \%) were procured for the production of the $\mathrm{Zn}-40 \mathrm{Al}$ alloy to be produced as the matrix for the composite. The sample designations for the fabricated $\mathrm{Zn}-40 \mathrm{Al}$ based composites are presented in table 1. Chemically pure silicon carbide particles $(\mathrm{SiC}, 1 \mu \mathrm{m})$, were selected as reinforcement for the composite productions with different contents. SEM images of untreated and $\mathrm{Cu}$-coated $\mathrm{SiC}$ particles were shown in figure 1.

\begin{tabular}{|c|c|c|c|c|}
\hline \multirow{2}{*}{ Material } & \multicolumn{4}{|c|}{ Elements } \\
\cline { 2 - 5 } & $\mathrm{Al}$ & $\mathrm{Cu}$ & $\mathrm{Mg}$ & $\mathrm{Zn}$ \\
\hline ZA40 alloy & $38-41$ & $2.0-2.5$ & $0.01-0.02$ & Balance \\
\hline
\end{tabular}

\section{Fabrication of the composites}

The fabrication of the $\mathrm{Zn}-40 \mathrm{Al} / \mathrm{SiCp}$ composites was performed using semi-solid stir-casting process consisted of the following steps: (1) $\mathrm{Zn}-40 \mathrm{Al}$ alloy was molten at $700^{\circ} \mathrm{C}$ in stainless steel crucible and then cooled to a semi solid state (at a temperature of about $510{ }^{\circ} \mathrm{C}$ ); (2) The SiCp preheated at $500{ }^{\circ} \mathrm{C}$ to remove moisture and to improve wettability with $\mathrm{Zn}$-Al alloy was added into the semi-solid matrix alloy, stirred at $850 \mathrm{r} / \mathrm{min}$ for $30 \mathrm{~min}$; (3) The semi-solid slurry was then poured into a preheated container $\left(480^{\circ} \mathrm{C}\right)$ and allowed to solidify to obtain composite billets.

"Corresponding Author: Dr. Fu yuan Dong, School of Materials Science and Engineering, North Minzu University, Yinchuan 750021, China; E-mail: fydong@alum.imr.ac.cn

Citation: Geng GH, Wang DX, Xue PH, Dong FY (2018) Microstructure, Mechanical Properties and Wear Behaviour of Semi-solid Stir Casting SiC Reinforced Zn-40Al Based Composites. Int J Metall Mater Eng 4: 145. doi: https:// doi.org/10.15344/2455-2372/2018/145

Copyright: (C) 2018 Geng et al. This is an open-access article distributed under the terms of the Creative Commons Attribution License, which permits unrestricted use, distribution, and reproduction in any medium, provided the original author and source are credited. 
Citation: Geng GH, Wang DX, Xue PH, Dong FY (2018) Microstructure, Mechanical Properties and Wear Behaviour of Semi-solid Stir Casting SiC Reinforced Zn-40Al Based Composites. Int J Metall Mater Eng 4: 145. doi: https://doi.org/10.15344/2455-2372/2018/145

Page 2 of 7

\section{Microstructural examination}

Microstructure observation was carried out by scanning electron microscope (SEM). The samples for the examination were metallographically polished and etched using hydrofluoric acid solution for $5 \mathrm{~s}$ before the microstructural investigation was carried out.

\section{Mechanical testing}

The hardness, tensile properties and wear behavior of the composites were evaluated using Brinell hardness testing, tensile testing, and wear testing, respectively. The specimens for hardness test were ground and polished before carrying out multiple hardness indentations. The hardness values within the range of $\pm 2 \%$ were averaged to obtain the hardness value.

A universal tensile testing machine operated at a strain rate of 0.5 $\mathrm{mm} / \mathrm{min}$ was used for the tensile testing of the composite samples which were machined as a bone-shape with a gauge length of $25 \mathrm{~mm}$ and a diameter of $5 \mathrm{~mm}$. The samples were pulled in tension to fracture and stress-strain curves were generated for each sample in accordance with ASTM 8M-91 Standard (1991). The tensile properties evaluated from the stress-strain curves are yield strength, tensile strength and percent elongation. Multiple tensile tests were performed for each test composition of the composite to guarantee the reliability and reproducibility of the results.

Wear tests were carried out at RM (room temperature) with a wear testing equipment controlled by computer. The external diameter of the counterpart discs was $3 \mathrm{~mm}$ and it was made of induction quenched GCR15 steel, which had a hardness of HRC 60. Abrasion test were performed at a constant load of $1850 \mathrm{~N}$. For each sample, the test was carried out at a constant sliding speed of $0.1 \mathrm{~m} / \mathrm{s}$ for $25 \mathrm{~min}$. Each wear sample was ultrasonically cleaned in acetone and weighed by an electronic balance with an accuracy of $0.1 \mathrm{mg}$ before and after the wear test to measure the mass loss. The friction coefficient of the sample was recorded simultaneously by the computer. Three tests were carried out for each set of sample. The worn surfaces were analyzed by SEM.

\section{Result and Discussion}

\section{Microstructural characterization}

Figure 2 shows the microstructures of the $\mathrm{Zn}-40 \mathrm{Al}$ alloy and the selected $\mathrm{Zn}-40 \mathrm{Al} / \mathrm{SiC}$ composites. The microstructure of the $\mathrm{Zn}-40 \mathrm{Al}$ alloy in the cast condition forms $\alpha-\mathrm{Al}$ dendrites and $\mathrm{Zn}+\eta$ phase-rich in interdendritic spaces. The addition of copper influences the formation of intermetallic $\varepsilon$ phases $\left(\mathrm{CuZn}_{4}\right)$ in the interdendritic regions. In the
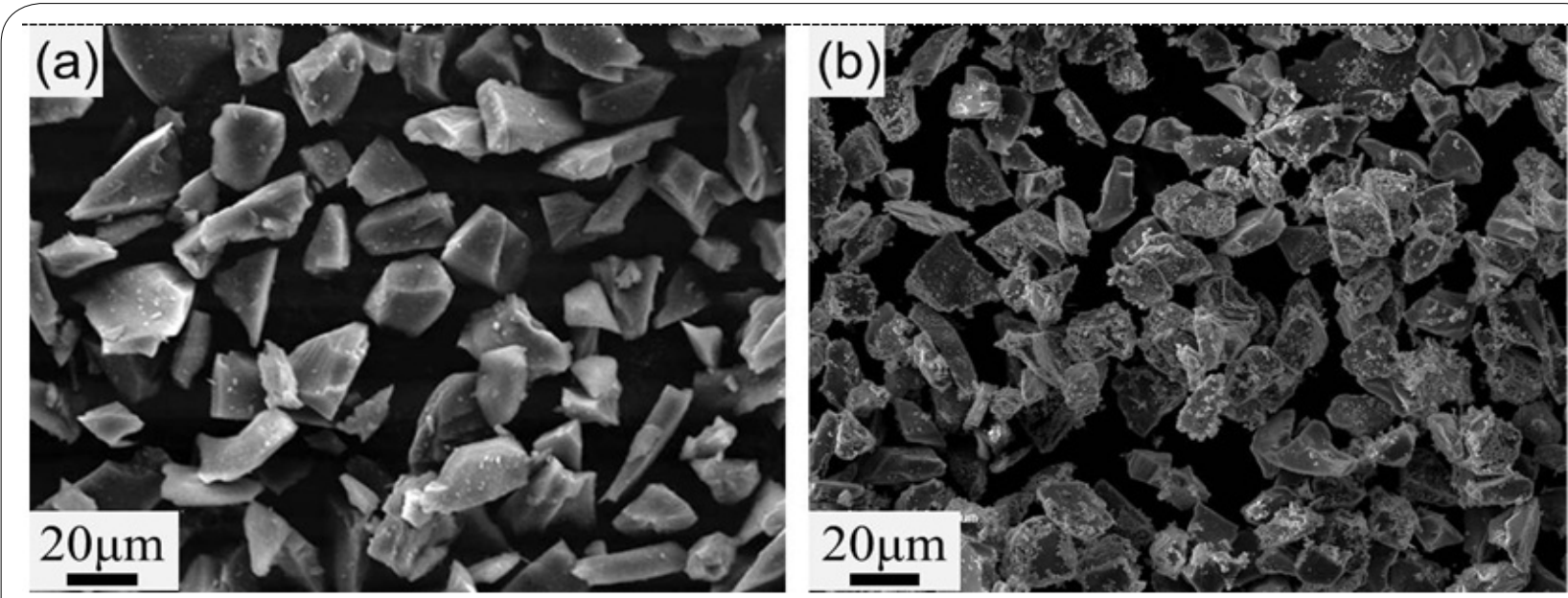

Figure 1: SEM images of (a) untreatedand (b) Cu-coated SiC particles.
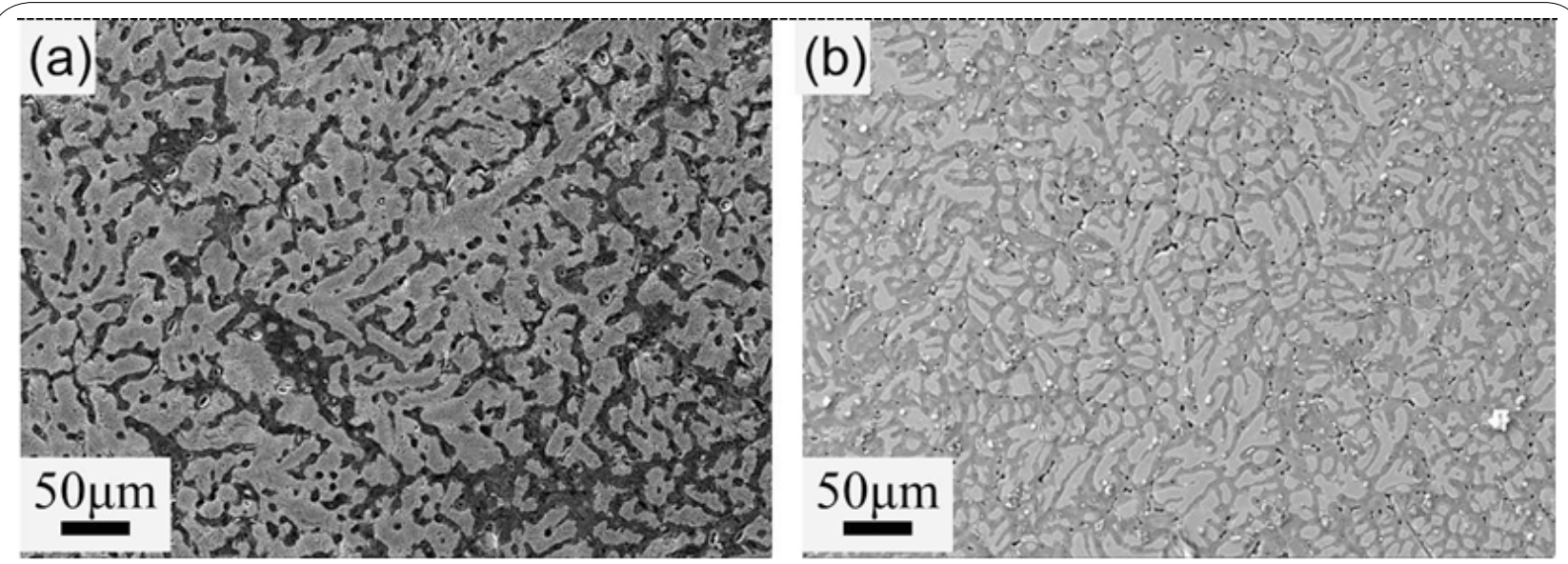

Figure 2: Representative micrograph showing (a) the $\mathrm{Zn}-40 \mathrm{Al}$ alloy microstructure, (b) the microstructure of the $\mathrm{Zn}-40 \mathrm{Al}$ based composite containing $0.5 \mathrm{wt} \% \mathrm{SiC}$ 
Citation: Geng GH, Wang DX, Xue PH, Dong FY (2018) Microstructure, Mechanical Properties and Wear Behaviour of Semi-solid Stir Casting SiC Reinforced Zn-40Al Based Composites. Int J Metall Mater Eng 4: 145. doi: https://doi.org/10.15344/2455-2372/2018/145

Page 3 of 7

composites with different contents of $\mathrm{SiC}$, the microstructures appear very similar, consisting of the dendritic structure same with that of the $\mathrm{Zn}-40 \mathrm{Al}$ alloy matrix and well distributed reinforcing particles in the interdendritic regions. Regardless of the contents, dendrites percentages are slightly higher than in the $\mathrm{Zn}-40 \mathrm{Al}$ alloy without $\mathrm{SiC}$. Nevertheless, the addition of $\mathrm{SiC}$ of the base alloy resulted in the occurrence of finer grains, same with the observation in the previous investigations [12-15]. Similarly, addition of $\mathrm{SiC}$ promotes a more uniform distribution of precipitates presence in the interdendritic regions. Similar microstructural features have been reported by Alaneme who worked on $\mathrm{Zn}-40 \mathrm{Al}$ based composites reinforced with bamboo leaf ash and silicon carbide. However, the density measurements showed that the composites contained some porosities, and the amount of porosity in the composites increased with the increasing content of the $\mathrm{SiC}$ (Table 2).

\section{Mechanical behavior}

The Brinell hardness of the composites and matrix alloy is given in Table 2. The relation between the particles content and the hardness of the composites was plotted in Figure 3(a). As compared to the Zn$40 \mathrm{Al}$ matrix alloy, the hardness of the MMCs was higher, indicating the addition of $\mathrm{SiC}$ particles increased the hardness of the $\mathrm{Zn}-\mathrm{Al}$ alloy $[16,17]$. Furthermore, the hardness of the composites increased with increasing $\mathrm{SiC}$ content. The fine, hard and well dispersed $\mathrm{SiC}$ particulates was responsible for the improved hardness.

The profiles of ultimate tensile strength (UTS) of the composites as a function of $\mathrm{SiC}$ content were depicted in Figure 3(b). With the increase of $\mathrm{SiC}$ contents, the tensile strengths exhibited a tendency to decrease after the first rise. It indicated that compared with non$\mathrm{SiC}$ addition alloy, adding $0.5 \% \mathrm{SiC}$ can improve the tensile strength. When the alloy contains $0.5 \% \mathrm{SiC}$, the UTS value is $463 \mathrm{MPa}$ and the YS is $460 \mathrm{HB}$. The improving amplitudes reach $19.6 \%$ and $27.1 \%$, respectively. When adding $1.0 \%$ and $1.5 \% \mathrm{SiC}$, the tensile properties decline significantly compared to the composite with $0.5 \% \mathrm{SiC}$. And the total elongation (TE) decreases continuously with the increasing contents of SiC. The UTS increases from 387 to $463 \mathrm{MPa}$ while the TE decreases from $2.4 \%$ to $1.1 \%$ after incorporating 0.5 wt. \% in $\mathrm{SiC}$ particulates. The decrease in the TE of the composites with increasing $\mathrm{SiC}$ content may be due to the limited plastic deformation of the matrix by the particles and the deterioration of ductile matrix content when the amount of porosity in the composites increased with the increasing content of the SiC. Moreover, the residual stresses generated due to the large difference in thermal expansion coefficient between the matrix and particles would probably contribute to the brittle nature of the composites [18].

The fracture morphologies of the $\mathrm{Zn}-40 \mathrm{Al} / \mathrm{SiP}_{\mathrm{p}}$ composites are shown in figure 4 . The presence of small dimples and tearing ridge indicates that the fracture mechanism of the composite with $0.5 \% \mathrm{SiC}$ is principally ductile fracture containing some brittle failure. It can be seen that the amount of dimples decrease with the increase of $\mathrm{SiC}$ content while the flat regions exhibit an opposite tendency. It is worth noting that, in addition to the fracture features mentioned above, shrinkage cavities can also be found on the fracture surfaces of the composites with $1.0 \%$ and $1.5 \% \mathrm{SiC}$, which can be attributed to the dendrite segregation in non-equilibrium solidification process.

The strength and hardness of the $\mathrm{Zn}-40 \mathrm{Al}$ alloy and $\mathrm{Zn}-40 \mathrm{Al} / \mathrm{SiC}$ composites are listed in Table 2 . The ratio of hardness to strength has been plotted as functions of the $\mathrm{SiC}$ content, as shown in figure3 (c). The ratio of hardness to strength is approximately equal to 3 in theZn$40 \mathrm{Al}$ alloy and $\mathrm{Zn}-40 \mathrm{Al} / 0.5 \% \mathrm{SiP}$ composites, but obviously increased to high value in the $\mathrm{Zn}-40 \mathrm{Al} / 1.0 \% \mathrm{SiP}_{\mathrm{p}}$ and $\mathrm{Zn}-40 \mathrm{Al} / 1.5 \% \mathrm{SiP}_{\mathrm{p}}$ composites.

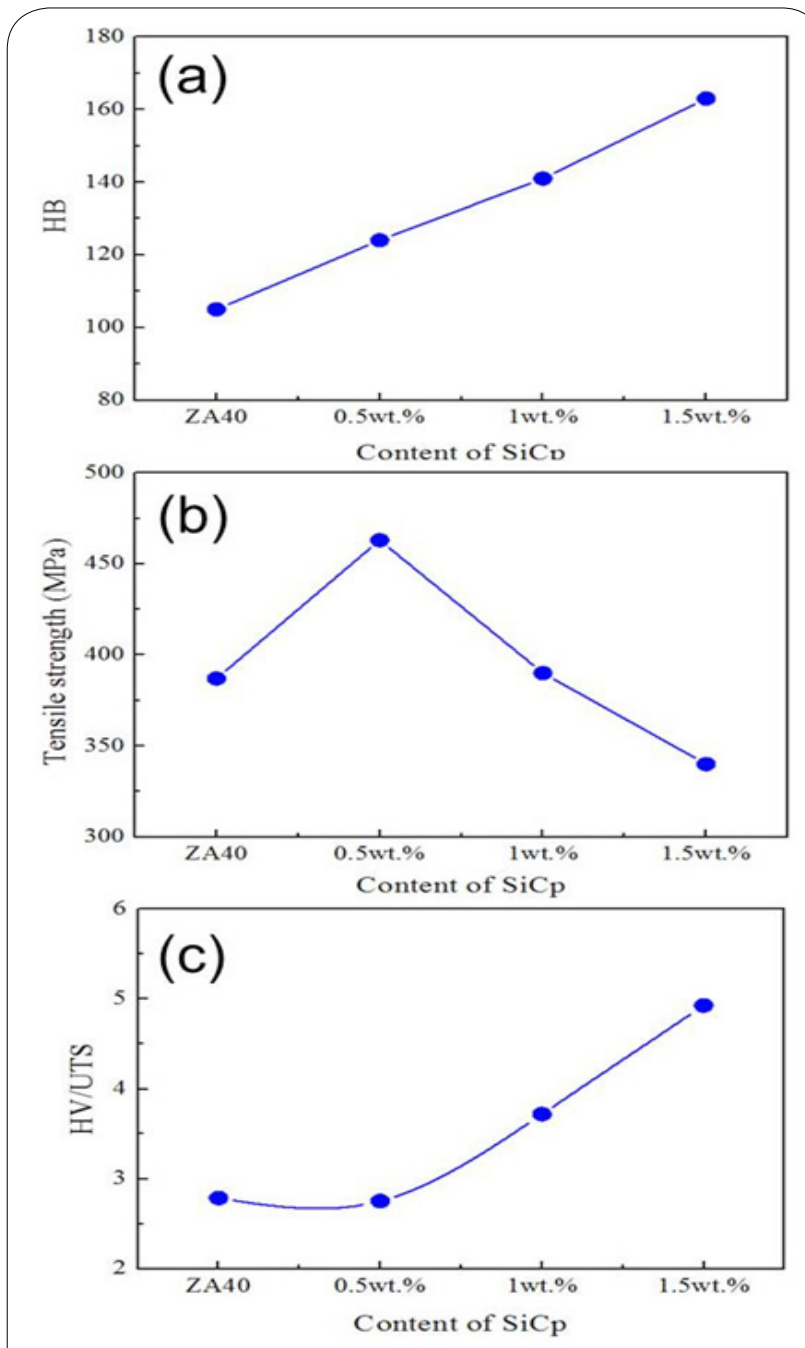

Figure 3: Effect of $\mathrm{SiC}$ content on hardness, tensile strength and HV/ UTS of $\mathrm{Zn}-40 \mathrm{Al} / \mathrm{SiC}_{\mathrm{p}}$ composites.

\begin{tabular}{|c|c|c|c|c|c|c|c|}
\hline & \multicolumn{1}{|c|}{ HB } & UTS (MPA) & YS & EL & HV (MPa) & HV/UTS & Porosity (\%) \\
\hline ZA40 & 105 & 387 & 362 & 2.4 & 1078 & 2.79 & 2.86 \\
\hline 0.5 wt.\% & 124 & 463 & 460 & 1.1 & 1274 & 2.75 & 3.07 \\
\hline 1.0 wt.\% & 141 & 390 & 388 & 0.2 & 1450.4 & 3.72 & 4.73 \\
\hline 1.5 wt.\% & 163 & 340 & 339 & 0.1 & 1675.8 & 4.93 & 7.22 \\
\hline
\end{tabular}

Table 2: Material properties of the $\mathrm{Zn}-40 \mathrm{Al}$ alloy and reinforced-composite samples. 
Citation: Geng GH, Wang DX, Xue PH, Dong FY (2018) Microstructure, Mechanical Properties and Wear Behaviour of Semi-solid Stir Casting SiC Reinforced Zn-40Al Based Composites. Int J Metall Mater Eng 4: 145. doi: https://doi.org/10.15344/2455-2372/2018/145

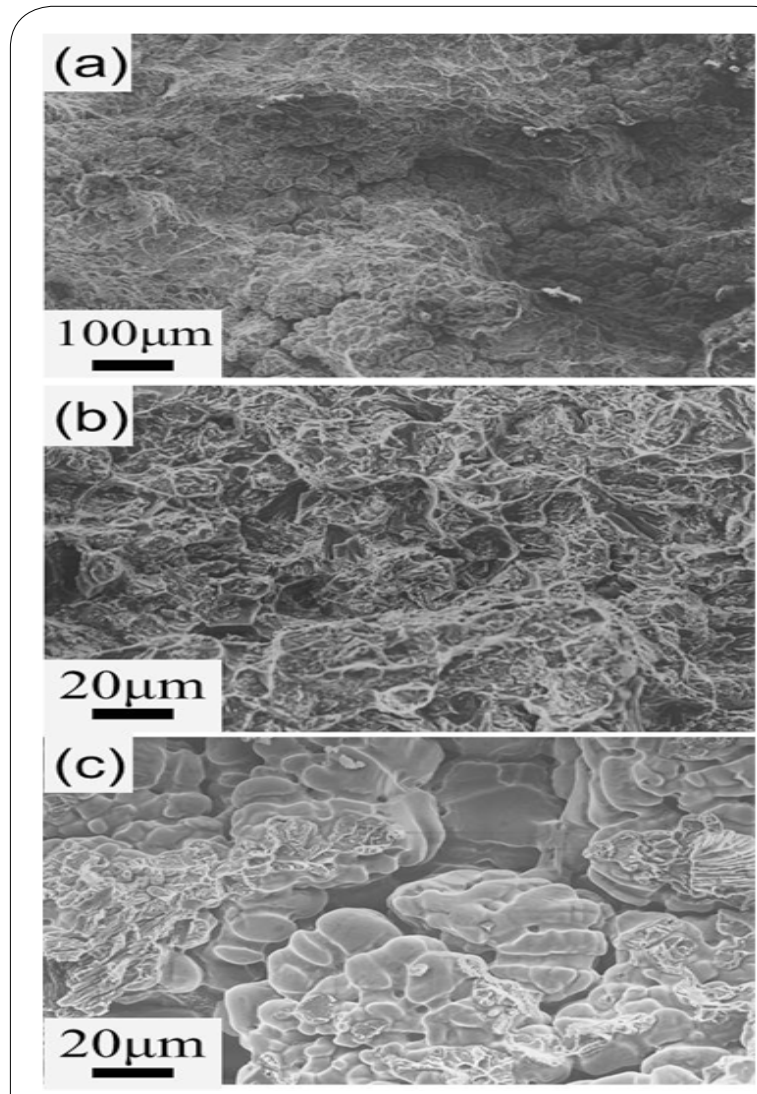

Figure 4: SEM fractrographs of $\mathrm{Zn}-40 \mathrm{Al} / \mathrm{SiC}$ composites with different $\mathrm{SiC}$ contents: (a) $0.5 \%$; (b) $1.0 \%$; (c) $1.5 \%$.
Following the analyses of Zhang et al. [19], the ratio of hardness to strength should be related to the difference in the shear ability of various materials, which can be schematically plotted versus the value $\alpha$ [20]. This parameter $\left(\alpha=\tau_{0} / \sigma_{0}\right)$ related with strength of materials was induced in the Ellipse criterion proposed by Zhang and Eckert to explain the deformation and failure behaviors in different materials [19-21], where $\sigma_{0}$ and $\tau_{0}$ are critical normal and shear fracture strength. It can be concluded from these results above that the mechanical characteristics in the $\mathrm{Zn}-40 \mathrm{Al}$ alloy and $\mathrm{Zn}-40 \mathrm{Al} / \mathrm{SiCp}$ composites should be mainly affected by these variations, as illustrated in figure 5. As the increase of $\mathrm{SiC}$ content, the dimension of crystals is smaller and the dendrite segregation becomes aggravation for ZA40-1.5\% $\mathrm{SiC}$. The brittle fracture and obvious shrinkage cavities can be seen in figure 4 (c). For the present $\mathrm{Zn}-40 \mathrm{Al} / 1.0 \% \mathrm{SiP}_{\mathrm{p}}$ and $\mathrm{Zn}-40 \mathrm{Al} / 1.5 \% \mathrm{SiP}_{\mathrm{p}}$ composites, the slip stress in the interior of grains increases so that the critical shear stress along the localized shear bands is greatly enhanced $[22,23]$.The critical normal stress decreased with the appearance of these pore- and crack-like defects. Accordingly, the ratio of hardness to strength can be affected by the refined structures and the induced porosity through influencing the $\tau 0$ and $\sigma_{0}$.

\section{Wear behavior of the composites}

The effect of sliding distance on the coefficient friction of $\mathrm{Zn}-40 \mathrm{Al}$ alloy and $\mathrm{Zn}-40 \mathrm{Al} / \mathrm{SiP}$ composites is seen in figure 6 . It is shown that with an increase in sliding distance, there is a gradual decrease in coefficient of friction for both the matrix alloy and the composites. Similar results have also been reported by other researchers [24,25]. At the beginning of the test run, contact between the sliding surfaces occurs at only a few highly protruding asperities [26]. In the case of the $\mathrm{Zn}-40 \mathrm{Al}$ alloy, asperity junction took place in the initial stage

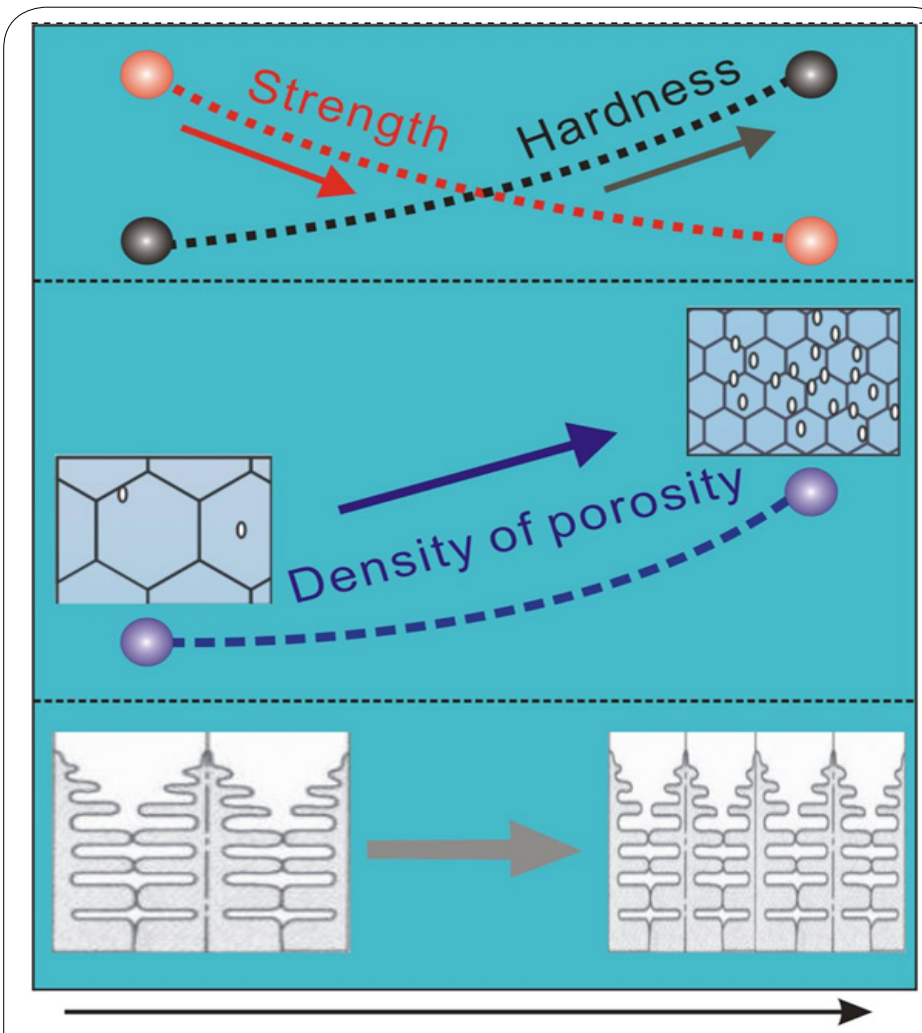

Figure 5: Effect of $\mathrm{SiC}$ content on hardness, tensile strength, density of porosity and dendrites of $\mathrm{Zn}-40 \mathrm{Al} / \mathrm{SiC}_{\mathrm{p}}$ composites. 
Citation: Geng GH, Wang DX, Xue PH, Dong FY (2018) Microstructure, Mechanical Properties and Wear Behaviour of Semi-solid Stir Casting SiC Reinforced Zn-40Al Based Composites. Int J Metall Mater Eng 4: 145. doi: https://doi.org/10.15344/2455-2372/2018/145

Page 5 of 7

due to the low hardness and inferior strength. Local tearing occurred in the vicinity of the asperities and resulted in coarse debris which can be confirmed by the following wear surfaces analysis. However, the friction coefficient values (Figure 6) do not show any marked sensitivity to the variation of the SiC content in the composites. The friction coefficient values of the composites are within the range of 0.25 and 0.35 .

Coefficient of friction values of $\mathrm{Zn}-40 \mathrm{Al}$ alloy and the developed composites are given in Table 3.It is obvious that the friction coefficient is slightly declined by adding $0.5 \% \mathrm{SiC}$ particles into the matrix. Further increasing the content of $\mathrm{SiC}$ to $1.0 \%$ results in a significant increase. Composite containing $\mathrm{SiC}(1.0 \%$ and $1.5 \%)$ having higher friction coefficient values. An increase of $31.4 \%$ and $11.0 \%$ in the coefficient of friction is observed for $1.0 \mathrm{wt} \%$ and $1.5 \mathrm{wt} \% \mathrm{SiC}$ composites respectively compare to the matrix alloy without $\mathrm{SiC}$.

The variation of the abrasion loss of $\mathrm{Zn}-40 \mathrm{Al} 40 / \mathrm{SiC}$ composites as a function of $\mathrm{SiC}$ content is depicted in figure. 7. It is observed that the abrasion loss decreases dramatically from alloy to composites, and slightly decreases with the increase of $\mathrm{SiC}$ content. Incorporating $0.5 \mathrm{wt} \% \mathrm{SiC}$ reduces the abrasion loss from $0.0266 \mathrm{~g}$ of the alloy to $0.0021 \mathrm{~g}$ of the composite. This can be explaned by the higher hardness of the composites and the good interfacial bonding between the matrix and reinforcement [27]. Furthermore, as shown in figure 8 , the extent of direct metal-to-metal contact can be ruduced by $\mathrm{SiC}$, which play the role of bearing load for protecting the matrix during the sliding process.
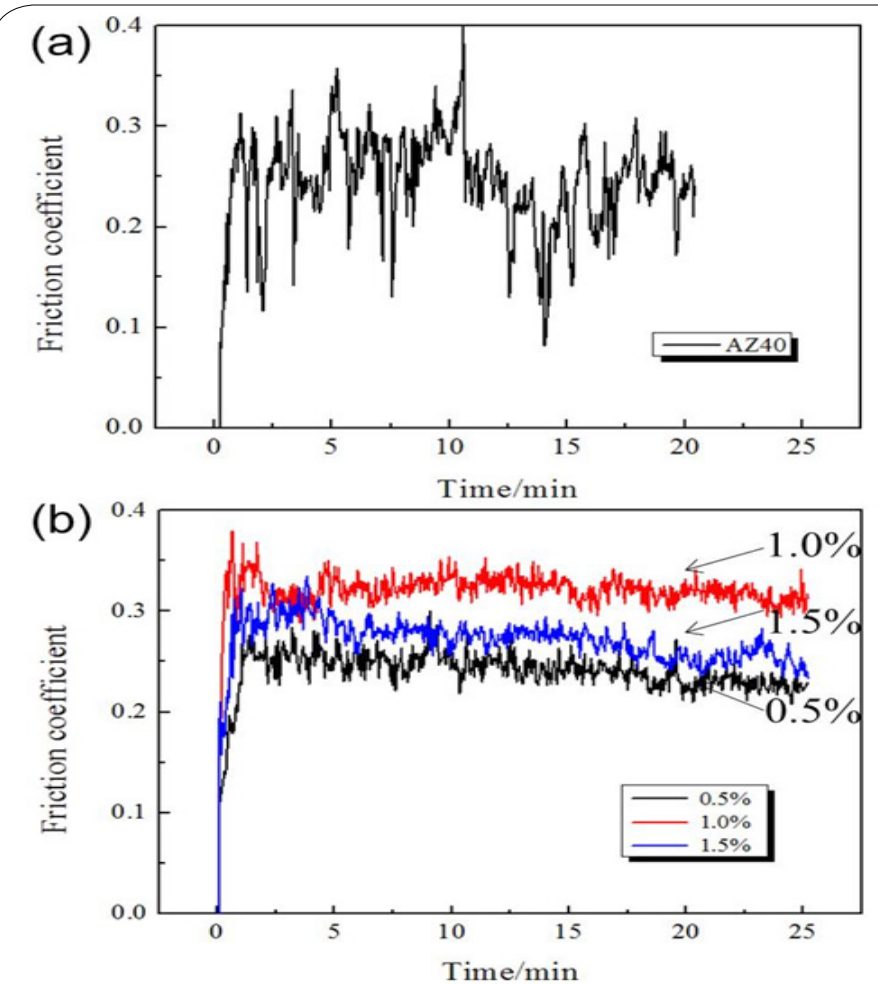

Figure 6: Variation of friction coefficient with test duration for $\mathrm{Zn}-40 \mathrm{Al}$ alloy and $\mathrm{Zn}-40 \mathrm{Al} / \mathrm{SiC}_{\mathrm{p}}$ composites.

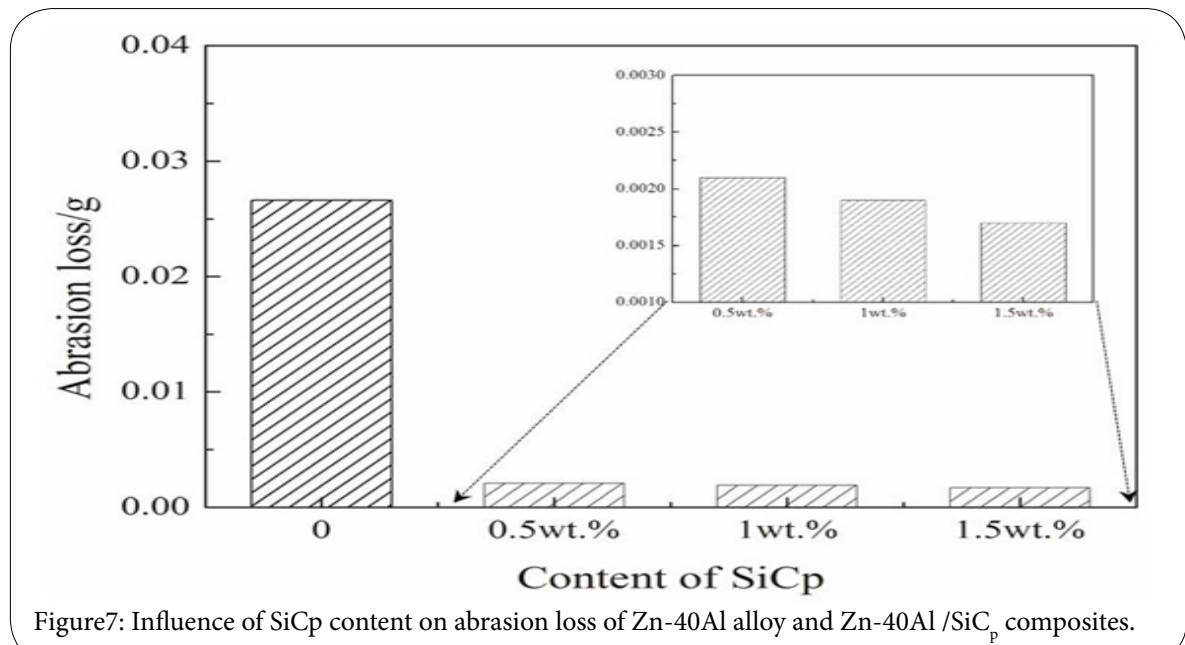


Citation: Geng GH, Wang DX, Xue PH, Dong FY (2018) Microstructure, Mechanical Properties and Wear Behaviour of Semi-solid Stir Casting SiC Reinforced Zn-40Al Based Composites. Int J Metall Mater Eng 4: 145. doi: https://doi.org/10.15344/2455-2372/2018/145

Page 6 of 7

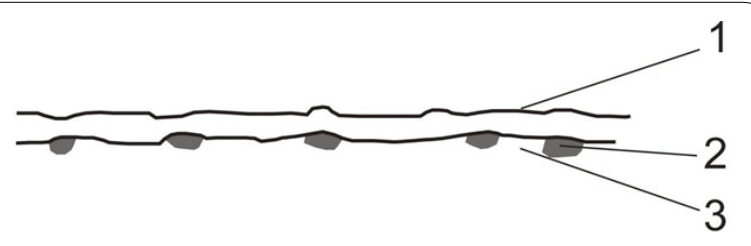

1-GCR15 steel 2-SiCp 3-Matrix

Friction surface schematic of allumen Figure 8: Friction surface schematic of $\mathrm{Zn}-40 \mathrm{Al} / \mathrm{SiC}_{\mathrm{p}}$ composites.
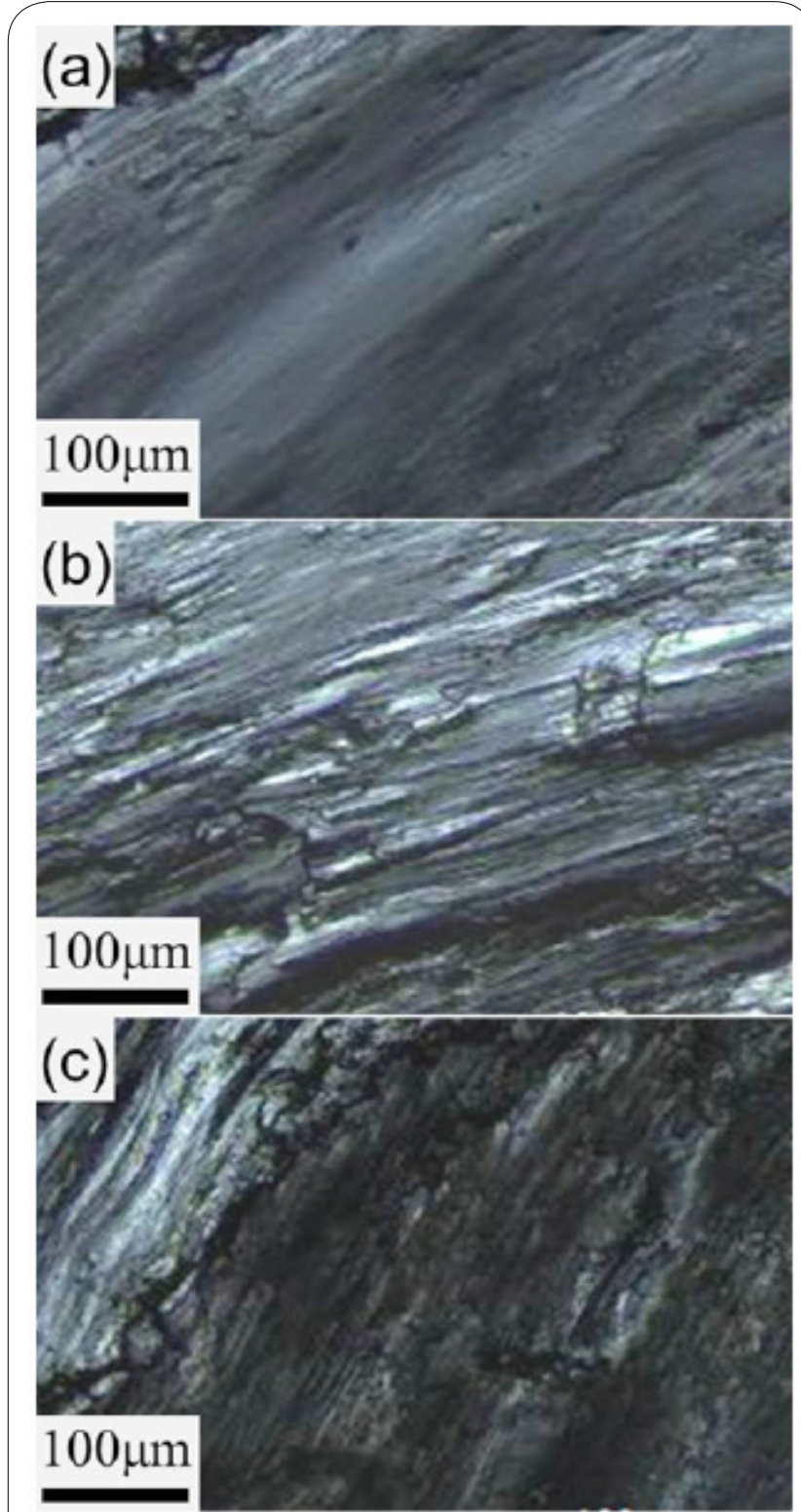

Figure 9: Effect of $\mathrm{SiC}$ content on tensile strength and elongation of ZA40-SiC in composites.

The SEM photographs of worn surfaces of $\mathrm{Zn}-40 \mathrm{Al}$ matrix alloy and $\mathrm{Zn}-40 \mathrm{Al} / \mathrm{SiC}$ composites can be seen in figure 9. There is a difference in the morphology of worn surfaces between the composites and the matrix alloy. The composites show fine grooves on the surface, whereas shallow and widergrooves are observed in case of the matrix alloy, which can explain the lower wear rates of the composites.

Porosity has a negative effect on their mechanical properties, which is the distinguishing feature of sintered materials. The influence of porosity on the wear behaviour of materials depends on the wear conditions and is not clearly identified. In the present investigation, these are not studied. Under certain conditions and depending on the pore size, porosity is observed to be beneficial for wear resistance by entrapping the wear debris and preventing the formation of large abrasive agglomerates. Pour filling superficially reinforce the material and result in diminishing plastic deformation and particle detachment around the pores.

From the results and discussions above, the major conclusions are summarized as follows:

1. The microstructures of the composites are similar, consisting of the dendritic structure of the $\mathrm{Zn}-40 \mathrm{Al}$ alloy matrix with fine dispersed $\mathrm{SiC}$. After adding $\mathrm{SiC}$, the microstructures of $\mathrm{Zn}-\mathrm{Al}$ alloys are refined. However, with the increase of $\mathrm{SiC}$ content, a number of shrinkage porosity occurs. The most effective refining appears in $\mathrm{Zn}-40 \mathrm{Al}-0.5 \% \mathrm{SiC}$. Adding $\mathrm{SiC}$ could refine the grain and abate the dendritic grainsby strongly pinning dislocations and subgrain boundary.

2. The hardness of the composites for all the composites were much higher than the $\mathrm{Zn}-\mathrm{Al}$ alloys, and increased with the increase of $\mathrm{SiC}$ content in the composites.

3. The tensile strength and yield strength of the composite with 0.5 wt $\%$ of $\mathrm{SiC}$ were higher than the $\mathrm{Zn}$-Al alloys, but decreased with the increase of $\mathrm{SiC}$ content in the composites, with a maximum reduction of $8.5 \%$ in tensile strength.

4. The wear resistance ability of the composites increases with increase in the weight percent of $\mathrm{SiC}$. As much as $90 \%$ decrease in abrasion loss was obtained for the $\mathrm{SiC}$ reinforced $\mathrm{Zn}-40 \mathrm{Al}$ composites containing $0.5 \mathrm{wt} \% \mathrm{SiC}$.

\section{Funding}

This work was financially supported by "Natural Science Foundation of Ningxia Province” under Grant no NZ17109.

\section{Data Availability Statement}

The data used to support the findings of this study are included within the article.

\section{Competing Interests}

The authors declare that they have no competing interests.

\section{References}

1. Ranganath G, Sharma SC, Krishna M (2001) Dry sliding wear of garnet reinforced zinc/aluminium metal matrix composites. Wear 251: 1408-1413.

2. Kumar P, Xu C, Langdon TG (2006) Mater. Sci Eng A 429:324.

3. Tjong SC, Chen F (1997) Wear behavior of as-cast ZnAl27/SiC particulate metal matrixcomposites under lubricated sliding condition. Metall Mater Tran A 28: 1951-1955. 
Citation: Geng GH, Wang DX, Xue PH, Dong FY (2018) Microstructure, Mechanical Properties and Wear Behaviour of Semi-solid Stir Casting SiC Reinforced Zn-40Al Based Composites. Int J Metall Mater Eng 4: 145. doi: https://doi.org/10.15344/2455-2372/2018/145

Page 7 of 7

4. Babic M, Slobodan M, Dzunic D, Jeremic B, Ilija B, et al. (2010) Tribological behavior of composites based on ZA-27 alloy reinforced with graphite particles. Tribol Lett 37: 401-410.

5. Bobic B, Bajic N, Jovanovic MT, Bobic I (2009) Microstructureand mechanical properties of Zn25Al3Cu based composites withlarge Al2O3 particles at room and elevated temperatures. Metall. J Mater Eng 15: 245-255.

6. Xu Z, Yan J, Zhang B, Kong X, Yang $S$ (2006) Behaviors of oxide film at the ultrasonic aided interaction interface of $\mathrm{Zn}-$ Alalloy and Al2O3p/6061Al composites in air. Mater Sci Eng A 415: 80-86.

7. Mitrovic' S, Babic' M, Bobic' I (2007) ZA-27 alloy composites withAl2O3 particles. Tribol Ind 29: 35-41.

8. Bobic' B, Vencl A, Babic' M, Mitrovic' S, Bobic' I (2014) The influence of corrosion on the microstructure of thermally treatedZA27/SiCp composites. Tribol Ind 36: 33-39.

9. NAI SM L, GUPTA M (2002) Influence of stirring speed on the synthesis of $\mathrm{Al} / \mathrm{SiC}$ based functionally gradient materials. Composite Structures 57: 227-233.

10. Cook AJ, Werner PS (1991) Pressure infiltration casting of metal matrix composites. Materials Science and Engineering: A 144: 189-206.

11. Hashim J, Looney L, Hashmi MSJ (1999) Metal matrix composites: Production by the stir casting method. Journal of Materials Processing Technology $92-$ 93: 1-7.

12. Hong-wei $Z$, Lin G, Li-na G, Lu-jun $H$ (5010) Effects of SiC particle pretreatment and stirring parameters on the microstructure and mechanical properties of SiCp/Al-6.8Mg composites fabricated by semi-solid stirring technique. Materials Science and Engineering A 528: 513-518.

13. Valdez S, Campillo B, Perez R, Martinez L, Garcia HA (2008) Synthesis and microstructural characterization of $\mathrm{Al}-\mathrm{Mg}$ alloy-SiC particle composite. Materials Letters 62: 2623-2625.

14. Murthy BS, Thakur SK, Dhindaw BK (2000) On the infiltration behavio of $\mathrm{Al}, \mathrm{Al}-\mathrm{Li}$ and $\mathrm{Mg}$ melts through SiCp bed. Metallurgical and Materials Transactions A 31: 319-325.

15. Tjong SC, Ma ZY (2000) Microstructural and mechanical characteristics of in situ metal matrix composites. Material Science and Engineering R 29: 49-113.

16. Chen T, Yuan C, Fu M, Ma Y, Li Y (2009) Friction and wear properties of castingin in-situ silicon particle reinforced ZA27 composites. China Foundry 6: $1-8$

17. Tjong SC, Chen F (1997) Wear behavior of as-cast ZnAl27/SiC particulate metal matrix composites under lubricated sliding condition. Metall Mater Tran A 28a: 1951-1955

18. Chen F, Wang T, Chen Z, Mao F, Han Q, et al. (2015) Microstructure, mechanical properties and wear behaviour of $\mathrm{Zn}-\mathrm{Al}-\mathrm{Cu}-\mathrm{TiB} 2$ in situ composites. Trans Nonferrous Met Soc China 25: 103-111.

19. Zhang P, Li SX, Zhang ZF (2011) General relationship between strength and hardness Materials. Science and Engineering A 529: 62-73.

20. Zhang ZF, He G, Eckert J, Schultz L (2003) Fracture mechanisms in bulk metallic glassy materials Phys Rev Lett 91: 045505.

21. Zhang ZF, Eckert J (2005) Unified tensile fracture criterion. Phys Rev Lett 94: 094301.

22. Dong FY, Zhang P, Pang JC, Chen DM, Yang K (2013) Optimizing strength and ductility of austenitic stainless steels through equal-channel angula pressing and adding nitrogen element. Materials Science \& Engineering A 587: 185-191.

23. Dong FY, Zhang P, Pang JC, Ren YB, Yang K, et al. (2015) Strength, damage and fracture behaviors of high-nitrogen austenitic stainless steel processed by high-pressure torsion. Scripta Materialia 96: 5-8

24. Thakur SK, Dhindaw BK (2001) The influence of interfacial characteristics between $\mathrm{SiCp}$ and $\mathrm{Mg} / \mathrm{Al}$ metal matrix on wear, coefficient of friction and microhardness. Wear 247: 191-201.

25. Ramesh CS, Ahamed A (2011) Friction and wear behaviour of cast Al 6063 based in situ metal matrix composites. Wear 271: 1928-1939.

26. Kumar S, Chakraborth M, Subramanya Sarma V, Murty BS (2008) Tensile and wear behaviour of in situ Al-7Si/TiB2 particulate composites. Wear 265 $134-142$

27. Ramesh CS, Ahamed A (2011) Friction and wear behaviour of cast Al 6063 based in situ metal matrix composites. Wear 271: 1928-1939. 